荤和よび肝転移をきたした直腸粘液癌の症例

\begin{tabular}{|c|c|c|c|c|}
\hline 根木 & 逸郎 & 浜中裕一郎 & 大石 秀三 & 本間 \\
\hline 美崎 ～ & 幸平 & 西田 峰勝 & 村田文一郎 & \\
\hline
\end{tabular}

\title{
A CASE OF PANCREAS AND LIVER METASTASIS OF MUCINOUS CARCINOMA OF THE RECTUM
}

\author{
Itsuro NEKI, Yuichiro HAMANAKA, Kiichi HONMA, \\ Shuzo OHISHI, Kohei MISAKI, Minekatsu NISHIDA \\ and Bunichiro MURATA
}

2nd Department of Surgery, Yamaguchi University School of Medicine

(Director : Prof. Koichi Ishigami)

索引用語：直腸粘液癌, 直腸癌の血行性転移

\section{はじめに}

今回われわれは, 下部直腸癌で, 腹会陰式直腸切断 術にて絶対治㾤切除を施行し, 術後 2 年を経て, 萍頭 部および肝に転移をさたした症例を経験した。組織学 的に直腸癌は細胞外に多量の粘液を産生する粘液癌で あった．荤頭部病変も肝病変も同様の組織像を呈し， 組織学的に転移巣であると考兄られた。

直腸癌の局所再発の所見がなく, 膵頭部之肝の坬立 性の病変であったので, 腪頭十二指腸切除術之肝部分 切除術を施行した。術後さらに 1 年の延命をみたので 若干の考察を加兄て報告する.なお臨床病理学的所見 の記載は大腸癌取扱い規約 ${ }^{1}$, 膵癌取扱い.規約 ${ }^{21}$ とよっ た.

患者：56歳, 男性.

\section{症例}

主訴：黄疾。

家族歴：特記すべきことなし。

既往歴: 昭和56年 5 月 18 日, 直腸癌の䛦断にて根治 術を受けたが，その他特記することなし、直腸癌の病 理学的所見は, 腫瘤型で $\mathrm{Rb}, 4 \times 3.5 \mathrm{~cm}, \mathrm{a}_{1}, \mathrm{P}_{0}, \mathrm{H}_{0}, \mathrm{n}_{2}$ (十) $(252,251), \mathrm{ly}_{2}, \mathrm{v}_{0}, \mathrm{R}_{3}$ であった。組織学的診断は 粘液癌であった（図 1 ).

現病歴：直腸癌根治術後, 経過良好で社会復帰して

$<1985$ 年 3 月13日受理 $>$ 別刷請求先：根木 逸郎

$\bar{T} 755$ 宇部市小串1144 山口大学医学部第 2 外科
因 1 直腸癌組織所見：細胞外に豊富な粘液を産生す る粘液癌であった $(\times 40)$.

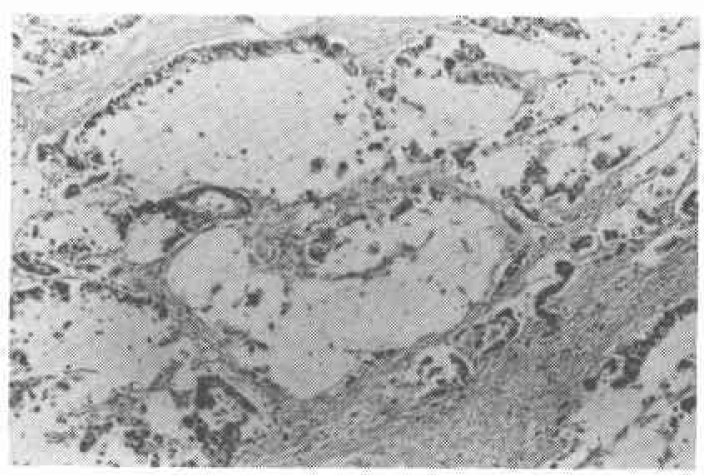

いた。昭和58年 5 月末, 術後 2 年して皮膚の黄染に気 づき，同時に全身倦总感を訴兄来院した。

入院時現症：皮薯, 眼䀫結膜に黄染があり, 腹部に は左下腹部に単孔式の人工肛門を認めるほかは腫瘤は 触知せず，また会陰部にも腫瘤は認めず，両側単径部 のリンパ節腫脹も認めなかった。

超音波検查：胆亳と総胆管の著明な払張を認め, ま た脺頭部に総胆管末端に接し, 径 $2 \mathrm{~cm}$ の腫瘤を認めた (図 2).

血液学的所見：赤血球 $476 \times 10^{4}$, 白血球 5,400 , Total Bilirubin $8.9 \mathrm{mg} / \mathrm{dl}$, Direct Bilirubin $6.0 \mathrm{mg} / \mathrm{dl}$, LAP 140U, Alkaline Phosphatase 122U, GOT 116U, GPT $216 \mathrm{U}, \gamma$-GPT $710 \mathrm{U}, \mathrm{LDH} 222 \mathrm{U}$ と閉塞性黄㾝のパ 
図2 超音波所見：苹頭部に, 执張した総胆管（細矢

印）に接して径 $2 \mathrm{~cm}$ の腫瘤を認めた（太矢印）。

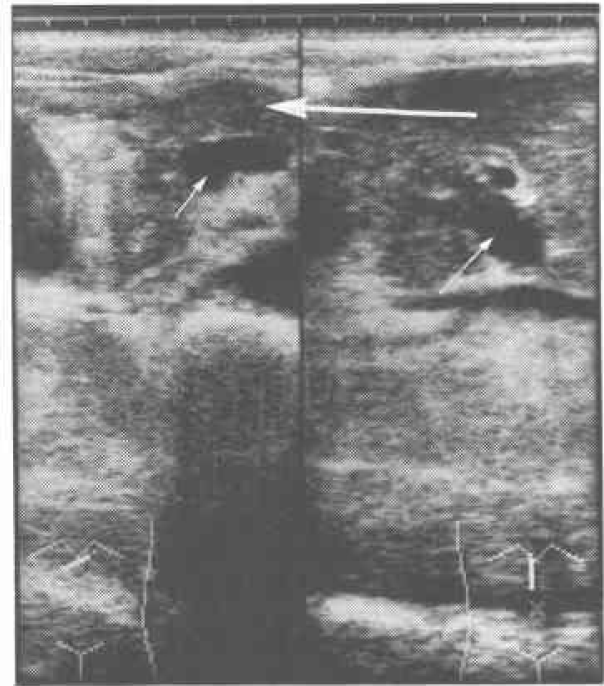

ターンを示した。

以上の所見より，䐙頭部癌の臨床診断のもと, Total Bilirubin が $10 \mathrm{mg} / \mathrm{dl}$ 以下であったので, 減黄術を行5 ことなく昭和58年 6 月 2 日，開腹術を施行した。

手術所見：腹膜転移はなく, 腹水も認めなかった。 荤頭部に一致して径 $2 \mathrm{~cm}$ の腫瘤を触知し, また, 肝の 右葉前下区域の下縁に径 $3 \mathrm{~cm}$ の腫瘤を認めた，桠の可 動性は良好で, 局所リンパ節の腫脹も認めなかった。 下腹部にも腫瘤などを触れず，直腸癌の局所再発を疑 わせる所見は全く存在しなかった。

術中の局所所見から, 腪頭部癌と診断し, 㬸頭十二 指腸切除術を施行した。肝は楔状に部分切除を行った。

切除標本の肉眼所見：荤頭部に一致し, 総胆管末端

\section{図 3 切除標本：腪頭部に総胆管に接して $2.3 \times 1.6 \times$}

$1.5 \mathrm{~cm}$ の白色調を帯びた腫瘤を認めた。

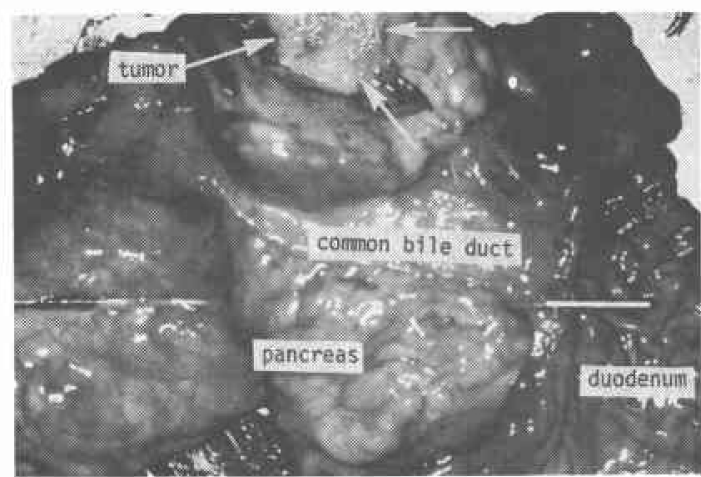

因 4 䐙腫瘍の組織像：a. 粘液産生能の強い一部腺 管構造をむった癌病巣を認めた $(\times 40)$. b. 腫暘組織 内の神経周囲侵畩 $(\times 100)$.

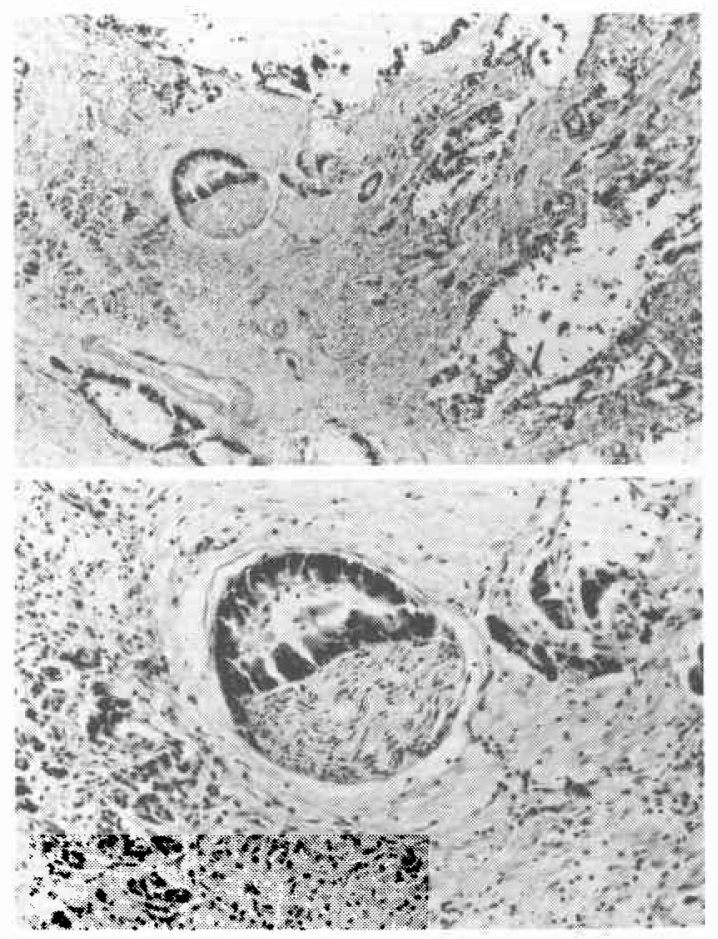

近く, 十二指腸開口部から $1.5 \mathrm{~cm}$ の蔳内に $2.3 \times 1.6 \times$ $1.5 \mathrm{~cm}$ の白色調を帯びた弾性硬の腫瘤を認めた（図 $3)$.

肝の腫瘤は $2.5 \times 2.3 \times 1.8 \mathrm{~cm}$ の傘頭部と同様な白 色調を帯びた腫瘤であった。

苹癌取扱い規約に従 $と$, $\mathrm{S}_{1}, \mathrm{Rp}(-), \mathrm{CH}(+), \mathrm{DU}$ $(-), \mathrm{V}(-), \mathrm{A}(-), \mathrm{P}_{0}, \mathrm{H}_{1}(\mathrm{dex}), \mathrm{N}(-)$ であっ た.

再建は脞空腸端々吻合を嵌入法で行い，䐁，胆管， 胃の順に吻合した。

組織学的所見：膵頭部に粘液産生能の強い, 一部腺 管構造をもった癌病栄を認め(図 4), 神経周囲侵襲も 認めた (図 4 b)，肝の腫瘤も同様な組織像を呈し，膵 病巣, 肝病巣ともに直腸癌の組織像と酷似していた。

術後経過は良好で，昭和58年10月22日退院したが， 昭和59年 6 月 23 日, 再手術後 1 年を経過して, 肺転移, 骨転移をきたして死亡した。

\section{考察}

直腸癌の血行性転移のほとんどは肝転移で手術時肝 転移の頻度は $10 \%$ 内外とされている3) ．われわれの 
教室に扎いては, 昭和 44 年から昭和 58 年むでの 15 年間 に145例の直腸癌手術症例があり, このうち手術時肝転 移を認めたのは15例，10.3\%であった，異時性肝転移 の切除症例は 2 例, $1.4 \%$ で, 膵転移は本報告例だけで あった。

本症例は, 初回手術後 2 年の寛解期があり, 再手術 時局所再発の徵候はなく，下腹部拉よび膵周囲のリン 八節転移はなく，播種性転移も，また肺転移もなく， 脺頭部と，肝にだけ孤立性に転移巣を認め，䐙への転 移経路を考劣ると興味ある症例と言える。一般的に遠 隔転移の経路は, リンパ行性と血行性である。本症の 場合, 再手術時局所リンパ節の転移はなく, 播種性転 移もなかったことから血行性転移と考えられた。また 䐙とともに肝に転移を認め再手術時には肺，骨に転移 を認めなかったことより，経門脈性転移と考学られた。

最終的には, 病理組織学的に転移の判定を行った。 本症の直腸癌組織は粘液癌であったが，結腸癌におい てこの頻度は比較的低(、10111).

大腸癌の組織像はその組織発生が単純であるので胃 と比べると簡明である ${ }^{8}$. 大腸は腸腺由来の癌がほと んどであり，この中で吸収上皮を主とする分化型癌と， 粘液産生を主とする粘液癌とに大別できる ${ }^{\mathrm{B})}$. るちろ んこの区別は厳密なものではなく, 両者が混合してい る場合が多い，組織型による頻度は, 高分化型, 中分 化型腺癌が汪とんど80 90\%を占め ${ }^{8) 9}$ 粘液癌の頻度 は低い，能見ら $\left.{ }^{10}\right)$ にると大腸癌全体の $11.4 \%$ と報告

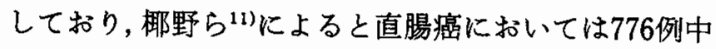
42例, $5.4 \%$ が粘液癌であった. 本報告例での直腸癌組 織は, 中分化型腺癌と混在するが, 主として粘膜下か ら筋層にかけて, 細胞外に多量の粘液を産生する粘液 癌であった。膵および肝の転移巣も同様に細胞外に多 量の粘液を産生する腫痬で直腸癌組織と酷似してい た.

粘液癌は通常の腺癌より予後が悪いとされてお $\eta^{8) 109}$, 能見ら ${ }^{10}$ によるとリンパ管侵襲を $68.4 \%$ に認め ており，P因子陽性る粘液癌に多いと報告している。 われわれの症例すリンパ管侵襲陽性であり, 絶対治瘺 切除が施行できたにるかかわらず, 術後 2 年を経て, 腪および肝再発をきたし，最終的には全身転移をきた して死亡したことから，極めて悪性度の高い癌である という印象を受けた。

また本症例の腪転移巣において神経周囲侵裂を認め たが，元来脺癌の特徽のひとつである神経周囲侵襲 を(2) 14)本症例のような転移巣に認めたことは, この成
立機序が，必ずしも荤癌自体の神経親和性によるもの ではなく, 構造上の特徵によるということを示して興 味深い.

\section{結語}

直腸癌にて腹会陰式直腸切断術, 絶対治瘾切除を施 行, 2 年後に茄頭部之, 肝に孤立珄に転移をきたした 症例を報告した。術中所見より膵腫瘤は原発性膵癌々 診断し, 荤頭十二指腸切除術, 肝部分切除を施行した。 その後な扣 1 年の延命をみたが，最終的には肺，骨転 移で死亡した。

直腸癌は粘液癌で, 莝, 肝の組織像も直腸癌のそれ と酷似して招り, 組織学的に転移と判定した。

\section{文 献}

1）大腸癌研究会編：大腸癌取扱い規約. 改訂第 2 版, 東京，金原出版，1983

2）日本龩藏病研究会編：䐙癌取扱い規約. 東京, 金原 出版, 1980

3）土屋周二：大腸癌. 外科診療 $21: 1625-1632$, 1979

4）大内明夫, 佐久間晃, 高橋正倫名 : 大腸癌の血行 珄転移例の检討一主として予後の面より一。癌の 臨 $27: 1739-1742,1981$

5）浜野恭一, 由里樹生, 秋本 伸法か：転移性肝癌火 対寸る肝切除術。消外 5:1125-1131，1982

6）奥山和明，磯野可一，佐藤裕俊注加：大腸癌肝転移 例飞対する集学的治療。日消外会誌 16 ： $1345-1351,1983$

7）池田考明, 池 秀之, 堀 雅晴洁か：大腸癌の臨床 病理学的变遷. 日本大腸肛門病会誌 37 : $597-602,1984$

8）喜納 勇：大腸癌の病理. 外科 Mook, No. 6, 東 京, 金原出版, 1979, p31-47

9）磯野可一, 斉藤登喜男, 佐藤裕俊注か：直腸癌の予 後に関する病理組織学的検討一とくに胃癌との比 較に扰いて一。癌の臨 $21: 905-909,1975$

10）能見伸八郎, 田中承男, 井口公雄浮か：大腸粘液癌 の検討. 日消外会誌 $15: 1376-1380,1980$

11）梛野正人, 高橋 孝, 太田博俊注か：占居部位別に みた直晹癌の臨床病理学的研究. 日消外会誌 $16: 1976-1985,1983$

12）黒田 慧, 和田祥之, 永井秀雄ほか：羘癌の進展様 式一特に䐙内進展およびリンバ節転移について 一. 日外会誌 $83 ： 1039-1042,1982$

13）東野義信, 永川宅和, 宮崎逸夫: 病理組織学的進行 度の対比よりみた小苹癌の外科治療の考方方。胆 と膵 $4: 1085-1090,1983$

14）松田真佐男, 二村雄次：橧頭部癌に捕ける神経周 囲侵䝺。日外会誌 $84 ： 719-728,1983$ 